\title{
Phenotype and Genotype Characterisation of the Asian Clam of the Genus Corbicula Megerle von Möhlfeld, 1811 (Venerida, Cyrenidae) from the East Coast of Peninsular Malaysia
}

\author{
ZHARIF RAMLI*1, VINOTHIRAN AYYAPAN ${ }^{1}$, AKRIMAH YUSOFF $^{1}$, AWENG EH RAK $^{2} \&$ \\ LEE SEONG WEI ${ }^{1}$ \\ ${ }^{1}$ Faculty of Agro Based Industry, Universiti Malaysia Kelantan Jeli Campus, 17600 Jeli, Kelantan, Malaysia; \\ ${ }^{2}$ Faculty of Earth Sciences, Universiti Malaysia Kelantan Jeli Campus, 17600 Jeli, Kelantan, Malaysia \\ *Corresponding author: zhariframli@yahoo.com \\ Received: 14 April $2020 \quad$ Accepted: 9 June $2020 \quad$ Published: 30 June 2020
}

\begin{abstract}
The Corbicula taxonomy in Malaysia is equivocal and scarcely being reported. This study aims to characterise phenotype and genotype of the Asian clam of the genus Corbicula (Mergele Von Mühlfeld, 1811) from three locations in east coast of Peninsular Malaysia. The phenotypic characterisation of the three population of the clam was evaluated on the basis of morphometric characters, while mtDNA cytochrome b (cytb) was used to characterise the genotypes. Results of morphometric analysis showed a significant difference $(\mathrm{p}<0.05)$ in shell height $(\mathrm{SH})$, shell width $(\mathrm{SW})$ and umbo length (UL) among three locations between the evaluated population. Discriminant analysis also revealed significant difference of the characters among the study sites. However, cluster analysis revealed an overlapping of morphometric characters among evaluated $C$. fluminea intricate complete separation between populations. Besides, a comparison of the Corbicula with the morphotypes and holotypes had proposed the Corbicula in this region known as C. fluminea. The genotypes characterisation using mtDNA cytb verifies the existence of $C$. fluminea. Phylogenetic trees demonstrated polymorphism and low genetic variances although geographically separated which parallel to the phenotypic characterisation. Thus, these findings enhance the knowledge on geographical variation and elucidate the complexity of taxa.
\end{abstract}

Keywords: Asian clam, Corbicula fluminea, genotypes, holotypes, phenotypes, taxonomy

Copyright: This is an open access article distributed under the terms of the CC-BY-NC-SA (Creative Commons Attribution-Non Commercial-ShareAlike 4.0 Internationa License) which permits unrestricted use, distribution, and reproduction in any medium, for non-commercial purposes, provided the original work of the author(s) is properly cited.

\section{INTRODUCTION}

The genus of Corbicula, the Asian clam is placed in the family of Corbiculidae and currently contains two species viz. C. fluminea and C. fluminalis, which are exclusively found in freshwater and brackish water, respectively (Hillis \& Patton, 1982; Mackie \& Claudi, 2009; Schmidlin, 2011). This clam is originated in Asia, including the archipelagos of Malaysia, and spread around the globe (Shamsul et al., 2017). This clam is commonly consumed by the people in the East coast region of Malaysia (Kelantan, Terengganu, and Pahang). However, the growth of the demand has threatened the Corbicula population in local water bodies. The harvesters yielded the Corbicula regardless of their sizes to cater to the market. Certainly, this clam can be found in the local market where at this time most of them were sourced from neighbouring countries such as Thailand and Cambodia.

Previously, the first record of Corbicula in Malaysia was identified as the early 1930s recorded in Mollusk Museum, Mahidol University Bangkok, Thailand. Another published record of Corbicula in Malaysia was recorded in 1940 known as $C$. tweediei (Prashad, 1940). This specimen was obtained from Perak, Malaysia and deposited in Raffles Museum, Singapore. In more recent, this clam was recognised as $C$. fluminea from Langat River, Selangor since it was genetically clustered in freshwater clades (Park \& Kim, 2003). The Corbicula taxonomy is complex due to low variation in shell shape, colour, and sculpture (Sousa et al. 2009; Pigneur et al. 2011). Furthermore, two shell forms were identified which may indicate different species existed. In fact, 
'form' reference is associated with the unique mitochondrial DNA sequences and combination characteristics such as colour and exterior shell shape variation being a significant reference for Corbicula identification (Hedtke et al., 2008).

Furthermore, within these identified species there is an equivocal in Corbicula taxa (Cheng, 2015). Previously, they were named based on the locality inhabitation such as C. sumatrana although the morphological characteristics are identical to $C$. fluminea, C. fluminalis and C. fluviatilis (Araujo et al., 1993; Schmidlin, 2011). Nevertheless, there is no agreement among researchers to authenticate the species and most of the evaluated Corbicula were synonymous with $C$. fluminea and $C$. fluminalis, currently relevant for species identification (Mackie \& Claudi, 2009; Schmidlin, 2011; Zeswita et al., 2016). In addition, they were synonimised due to inconsistent of the variation of the main unique characters among the species.

Earlier identification of Corbicula species could be carried out based on phenotypes analysis such as morphology and anatomy, behaviour or physiology (O'Leary \& Kaufman, 2012). Identification of Corbicula spp. through morphometric characteristics-based taxonomy was identified 200 species around the world (Pigneur $e t$ al., 2011). These Corbicula have equivalve, intergroplate near equilateral, profound and wide where $C$. fluminalis was found to be darker, taller and more triangular than $C$. fluminea in shell morphology (Araujo et al., 1993; Pigneur et al., 2011). However, the divergent in Corbicula morphology not sufficed to define the species due to genetics and environmental influences. Even though the uses of morphometric analysis have been equivocal among scientists since previous misnamed events, it is significant as prior work in characterising the Corbicula species.

Molecular approaches were employed in verifies the species and characterise the genotypes of the Corbicula. The mitochondrial and ribosomal DNA markers (mtDNA) were extensively employed in population analysis of aquatic species (Gomes et al., 2016; Zhu et al., 2018). The mtDNA marker such as cytochrome b (cytb) was used in several studies that proved successfully capable of identifying Corbicula species in low genetics polymorphism (Yamada et al. 2010; Gomes et al., 2016; Zhu et al., 2018). This genetic evidence could complement information and authenticate phenotypes analysis. The present study therefore aims to characterize the phenotypes and genotypes of the existing Corbicula species in East Coast region of Malaysia. The information of the Corbicula species obtained will give insight into the purposes of ecological management or aquaculture.

\section{MATERIALS AND METHODS}

\section{Sample Collection}

Corbicula fluminea was harvested from seven locations in three different states and the coordinates of the sampling locations as follows: Pahang; (i) Temerloh $\quad\left(3^{\circ} 42^{\prime} 15.2^{\circ} \mathrm{N}\right.$ $\left.102^{\circ} 43^{\prime} 70.6^{\prime \prime} \mathrm{E}\right), \quad$ Kelantan; $\quad$ (i)Tumpat $\left(5^{\circ} 37^{\prime} 08.3^{\circ} \mathrm{N} \quad 101^{\circ} 42^{\prime} 21.0^{\prime \prime} \mathrm{E}\right), \quad$ (ii) Jeli $\left(6^{\circ} 07^{\prime} 28.7^{\circ} \mathrm{N} 102^{\circ} 08^{\prime} 26.4^{\prime \prime} \mathrm{E}\right)$, (iii) Pasir Puteh $\left(5^{\circ} 51^{\prime} 09.1^{\circ} \mathrm{N} 102^{\circ} 24^{\prime} 26.5^{\prime \prime} \mathrm{E}\right)$, Terengganu; (i) Besut $\left(5^{\circ} 44^{\prime} 09.8^{\circ} \mathrm{N} 102^{\circ} 29^{\prime} 23.6^{\prime \prime} \mathrm{E}\right)$, (ii) Kuala Terengganu $\left(5^{\circ} 20^{\prime} 33.2^{\circ} \mathrm{N} 103^{\circ} 05^{\prime} 09.0^{\prime \prime} \mathrm{E}\right)$, and (iii) Marang $\left(5^{\circ} 11^{\prime} 47.7^{\circ} \mathrm{N} 103^{\circ} 11^{\prime} 37.1^{\prime \prime} \mathrm{E}\right)$. A total of 210 individuals of $C$. fluminea representing 30 individuals were collected from each location. They were collected in various ways such as basket, shovel, sand dredger, practically depending to the geographical condition. All samples were collected from the rivers except Jeli samples from a dam. The collected samples were kept in a jar supplemented with a wet tissue before they were brought back to Aquaculture laboratory, Universiti Malaysia Kelantan, Jeli Campus.

\section{Preparation of Samples}

The shells of the $C$. fluminea was gently opened using a scalpel. Once the shells were open, the visceral was dissected from the shell thoroughly. Then, visceral parts were preserved in 95\% ethanol and kept in the freezer. Any impairment during dissection would intricately measuring the shell character. After that, the shells were cleaned up with tap water to remove the attached meat or sediments. The shells were dried off using an oven for $24 \mathrm{~h}$ where the temperature was set up at $60{ }^{\circ} \mathrm{C}$. This process could improve the visibility of the morphometric character lines.

\section{Holotypes from Natural Museum}

Shell colour and shape were visually discriminated based on the European interior-surface morphotype descriptions: round dark-coloured (R), round light- 
coloured (Rlc) and saddle (S) (Pigneur et al., 2011; Penarubia et al., 2017). Then, they were compared with the deposited specimens in Mollusk Museum, Mahidol University, Bangkok, Thailand based on their morphological appearance's references. For this purpose, available museum collections with morphologically most similar and geographically nearest to the type were reviewed.

\section{Morphometric Characterization Analysis}

Fifteen morphometric characters were determined and measured. The morphometric measurements were taken by using a digital calliper (Absolute Digimatic Calliper/Mitutoyo (UK) Ltd the accuracy of $1 / 50 \mathrm{~mm}$ ). A total of 210 individuals from seven locations were measured. The morphometric characters had been measured as shown in Figure 1.

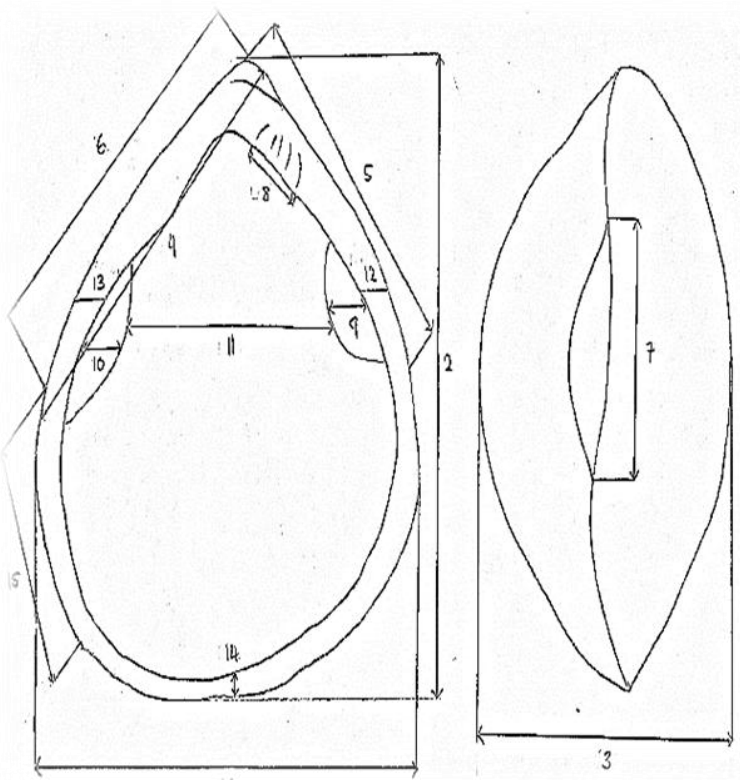

Figure 1. Morphometric characters indices (Redrawn from Hamli et al. 2015)

*1. Shell length (SL) 2. Shell height (SH) 3. Shell width (SW) 4. Umbo length (UL) 5. Anterior length (AL) 6. Posterior length (PL) 7. Ligament length (LL) 8. Cardinal tooth length (LCT) 9. Anterior adductor muscle scar width (AW) 10. Posterior adductor muscle scar width (PW) 11. Length from anterior adductor muscle scar to posterior adductor muscle scar (LPAS) 12. Length from anterior adductor muscle scar to anterior margin (AAAM) 13. Length from posterior adductor muscle scar to posterior margin (PAPM) 14. Length from ventral margin to the pallial line (PVM) 15. Ventral posterior margin length (VPM).

\section{DNA Extraction}

A total of $70 C$. fluminea from seven sites were dissected and tissue from the foot was cut and stored in alcohol at $4{ }^{\circ} \mathrm{C}$ until DNA extraction. The total genomic DNA was extracted following standard Protocol 6: Rapid Isolation of Mammalian DNA (Sambrook \& Russel, 2001). The quality of extracted DNA samples was evaluated by $1 \%$ agarose gel electrophoresis and quantified using Nanodrop 2000 UV-Vis Spectrophotometer (Thermo Scientific, Waltham, MA) at ratio reading of $260 / 280 \mathrm{~nm}$. The $260 / 280$ ratio purity of nucleic acids was determined based on the purity range, 1.8 to 2.0 (Desjardins \& Conklin, 2010). Then, each of the DNA was diluted to a concentration of 50-100 $\mathrm{ng} / \mu \mathrm{l}$ in TE buffer for polymerase chain reaction (PCR) amplification.

\section{PCR Amplification and Sequencing}

Primer pair of the $C$. fluminea cytb gene (F: 5'GAAGGGTTCATGCTAACGGAG-3'; R: 5'GTGGTGT ACTTATAGGGTCGGC-3') (Zhu et al., 2018) was used and produced 521 bp. The PCR amplification was performed in a total volume of $50 \mu \mathrm{l}$ containing $25 \mu \mathrm{l}$ PCR master mix (SMOBIO Technology, Inc. Taiwan), $0.5 \mu \mathrm{M}$ forward and reverse primers, $1 \mu \mathrm{l}$ of DNA template (50-100 ng) and $22 \mu 1$ of nucleus free water which make up to $50 \mu \mathrm{l}$ per tube. A 96 well thermal cycler (T-100, BioRad, USA) was used to perform PCR amplification using the following programme: Initial denaturing at $94{ }^{\circ} \mathrm{C}$ for $2 \mathrm{~min}$, followed by 35 cycles of $94{ }^{\circ} \mathrm{C}$ for $3 \mathrm{~min}$, annealing at $54{ }^{\circ} \mathrm{C}$ for $45 \mathrm{~s}$ and $72{ }^{\circ} \mathrm{C}$ for 2 min with a final extension at $72{ }^{\circ} \mathrm{C}$ for $5 \mathrm{~min}$. PCR amplicons were separated on $1 \%$ agarose gel electrophoresis and sequenced by accredited laboratory 1st Base, Malaysia.

\section{Data Analysis}

All the observations data for shell colour and shape were presented in percentages. Morphometric data were transformed into allometric ratios were subjected to shell length (SL) as a predictor in minimising the demographic influences. For the normality test, all data were assessed using Shapiro-Wilk's W and Levene's test for homogeneity of variances. The variances among $C$. fluminea populations were analysed using a oneway analysis of variance (ANOVA) where Tukey HSD posthoc test determined the significant 
difference at probability level, $\mathrm{p}<0.05$. Then, the discriminant analysis was used to analyse the data which emphasising the variation and brings out the strong component in the dataset (Pigneur et al., 2011). Cluster analysis was carried out to verify the discriminant analysis result. These analyses were carried out in statistical package for the social sciences (SPSS 19). The mtDNA sequences of cytb were aligned in consensus using Multiple Sequence Alignment CLUSTALW. The consensus gene sequences were analysed against the DNA nucleotides database using the Basic Local Alignment Search Tool (BLAST) and matched to identify the unknown sequences (Magare et al., 2015). Then, the phylogenetic analysis was performed through constructing the phylogenetic trees employed Maximum likelihood (ML), Neighbour-Joining (NJ) and Maximum Parsimony (MP) using software packages Molecular Evolutionary Genetics Analysis (MEGA 6.0) after phylogenetic neighbours of the Corbicula were identified. This analysis was constructed using 1000 bootstrap replicates and Polymesoda caroliniana (KC713250) was used as an out-group.

\section{RESULTS}

\section{Morphotypes and Holotypes Analysis}

Three morphotypes of Corbicula fluminea have been discriminated visually which correspond to the forms round dark-coloured (R), round lightcoloured (Rlc) and saddle (S) (Pigneur et al., 2011; Penarubia et al., 2017). Figure 2 shows the morphotypes percentage of the $C$. fluminea found in Kelantan, Terengganu, and Pahang. Round darkcoloured (R) morphotype dominating $C$. fluminea populations in Kelantan; $100 \%$ in Tumpat and Jeli and more than $60 \%$ in Pasir Puteh (Figure 2). In contrast, round light-coloured (Rlc) morphotype dominating Pahang and Terengganu's populations. Yet, $C$. fluminea in Kuala Terengganu was found dominated by saddle (S) morphotype (95\%). Based on the specimen references in Mollusk Museum, R and Rlc morphotypes primarily were referred to holotypes of $C$. fluminea, Corbicula sp, and $C$. lamarkiana (Table 1). Although various species were named for $\mathrm{S}$ morphotypes, they were synonymised based on the paratypes of $C$. petiti, $C$. lamarkiana, C. moreletiana, and C. ostiorum.

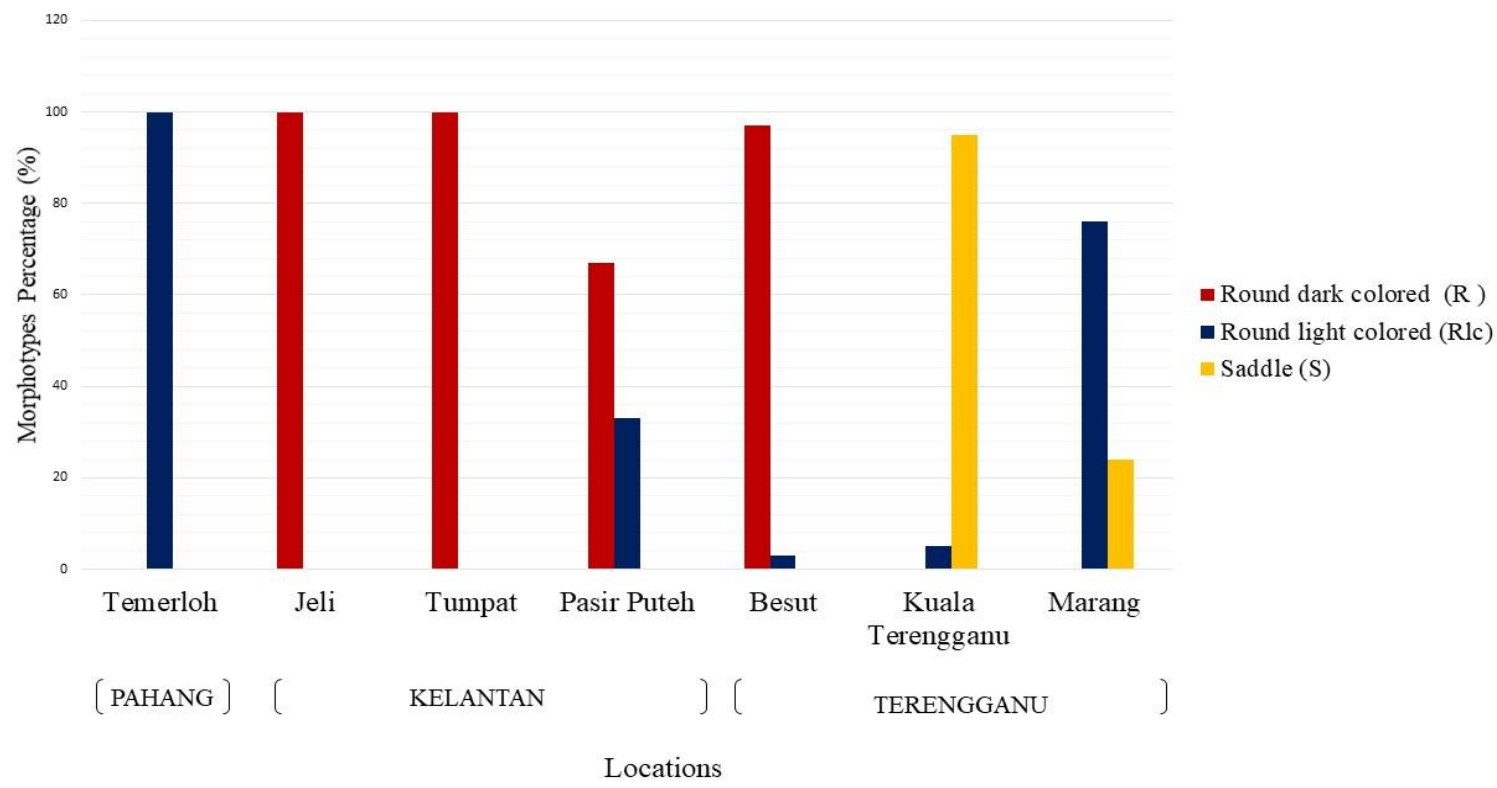

Figure 2. Percentage of Corbicula fluminea forms [Round dark colored (R), Round light colored (Rlc) and Saddle (S)] in seven locations in Pahang, Kelantan and Terengganu 
Table 1. Specimens of Corbicula spp. with location and their morphotypes deposited in Mollusk Museum, Mahidol University, Bangkok, Thailand

\begin{tabular}{llcc}
\hline Species and lot & Location & Type Specimen & Morphotypes \\
\hline Corbicula fluminea, TMMU43 & Tha Sa Ra, Kanchanaburi & paratype & $\mathrm{R}$ \\
Corbicula sp., DN81100-20 & Ban Ko Village, Chiang Rai & paratype & $\mathrm{R}$ \\
Corbicula fluminea, SMRL 2710 & River Chao Praya,Chainat & holotype & $\mathrm{R}$ \\
Corbicula lamarkiana, SMRL 2705 & River Chao Praya,Chainat & paratype & $\mathrm{R}$ \\
Corbicula fluminea, SMRL 6821 & River Ping, Chiang Mai & paratype & $\mathrm{R}$ \\
Corbicula fluminea, TMMBI4 & River Ping, Kamphaeng Phet & paratype & $\mathrm{Rlc}$ \\
Corbicula petiti, SMRL 2701 & Nong Han Lake, Sakhon Nakon & paratype & $\mathrm{S}$ \\
Corbicula lamarkiana, SMRL 2750 & Petburi River, Petburi & paratype & $\mathrm{S}$ \\
Corbicula moreletiana, SMRL 2765 & Irrigation canal, Ubon Ratchathani & paratype & $\mathrm{S}$ \\
Corbicula ostiorum, SMRL 2722 & Ta Pi River, Surat Thani & paratype & $\mathrm{S}$ \\
\hline
\end{tabular}

Therefore, it is more complicated to determine which species Corbicula (morphotype S) belongs to. Table 1 demonstrates the holotypes of the Corbicula spp. were deposited from different locations in Thailand. This reference restricted to the specimen in Thailand which deposited in the Mollusk Museum, Mahidol University, Thailand.

In the analysis of the morphometric characteristics, the SH/SL of the Corbicula in three states was found significantly different (Table 2). Furthermore, samples from Temerloh, Pahang show similar size to the sample from Pasir Puteh, Kelantan. Then, the SH/SL ratio of $C$. fluminea was found not significantly different between Tumpat and Jeli, Kelantan. The C. fluminea in Pasir Puteh, Kelantan was found to be similar in size to Besut, Terengganu (Table 2). Meanwhile, $C$. fluminea was found to be similar in SH/SL in Kuala Terengganu and Marang which was significantly different from the individuals found in Besut which recorded at $0.89 \pm 0.02$. Eight significant morphometric characteristics of $C$. fluminea in Tumpat and Jeli were recorded. There were varied in UL, PL, LL, LCT, AW, PW, AAAM and VPM characters in ratio to the SL (Table 2). Meanwhile, in Terengganu, 12 morphometric characters were found to be identical between Kuala Terengganu and Marang (Table 2).

However, only two characteristics such as AL and PL were found significantly different that distinguished $C$. fluminea from Kuala Terengganu and Marang. All morphometric characters of $C$. fluminea found in Besut were identical to the evaluated population from Pasir Puteh, Kelantan. The variation of the morphometric characters demonstrated the shell size, shape and age, which may be similar within and between individuals, as shown in Table 2.

Three canonical functions that had the Eigen value of $2.049,1.787$ and 1.431 were obtained. Function 1 explains the variance of $36.1 \%$ (Table 3 ). The larger the Eigen value, the more the function explains the variance in the dependent variable. Based on the morphometric measurements together, the first two discriminate functions clarified $67.5 \%$ (36.1\% and $31.5 \%$ ). According to the canonical discriminant function coefficients obtained for morphometric data, the most influential variables for Function 1 and $\mathrm{SH} / \mathrm{SL}, \mathrm{SW} / \mathrm{SL}$ and UL/SL. Figure 3 shows the distribution of the $C$. fluminea populations in seven locations in Kelantan, Terengganu, and Pahang. Based on this analysis, Function 1 indicates canonical correlation in SH/SL (-0.515), SW/SL ($0.161)$ and PW/SL (-1.92) and a positive correlation in LPAS/SL (0.376), LCT/SL (0.204) and LL/SL (0.170). For Function 2 positive canonical correlation was exhibited where SW/SL (0.529), LCT/SL (0.528), PW/SL (0.499) and LL/SL (0.489) were found to be significant. The discriminant functions are orthogonal which measures the shell shape (Function 1) are independent of shell size (Function 2).

Figure 4 presents the result obtained for canonical analysis of morphometric characters as a dendogram. The seven populations did not cluster together for morphometric characters according to the positions found in the dendogram collected. Therefore, it was not possible to get a complete separation of the seven locations. 
Table 2. The means \pm S.D of 14 morphometric characteristic proportion with shell length (SL) of Corbicula fluminea in Pahang, Kelantan and Terengganu

\begin{tabular}{|c|c|c|c|c|c|c|c|}
\hline & PAHANG & \multicolumn{3}{|c|}{ KELANTAN } & \multicolumn{3}{|c|}{ TERENGGANU } \\
\hline Parameter & Temerloh & Tumpat & Jeli & Pasir Puteh & Besut & Kuala Trg. & Marang \\
\hline $\mathrm{SH} / \mathrm{SL}$ & $0.931 \pm 0.05^{\mathrm{b}}$ & $0.845 \pm 0.03^{\mathrm{d}}$ & $0.878 \pm 0.07^{\mathrm{cd}}$ & $0.900 \pm 0.05^{\mathrm{bc}}$ & $0.890 \pm 0.02^{\mathrm{c}}$ & $0.967 \pm 0.04^{\mathrm{a}}$ & $0.985 \pm 0.05^{\mathrm{a}}$ \\
\hline SW/SL & $0.575 \pm 0.06^{\mathrm{e}}$ & $0.570 \pm 0.03^{\mathrm{e}}$ & $0.585 \pm 0.04^{\mathrm{de}}$ & $0.637 \pm 0.04^{\mathrm{bc}}$ & $0.611 \pm 0.03^{\mathrm{cd}}$ & $0.653 \pm 0.04^{\mathrm{ab}}$ & $0.675 \pm 0.04^{\mathrm{a}}$ \\
\hline UL/SL & $0.653 \pm 0.06^{\mathrm{c}}$ & $0.752 \pm 0.04^{\mathrm{a}}$ & $0.675 \pm 0.13^{\mathrm{bc}}$ & $0.655 \pm 0.03^{\mathrm{c}}$ & $0.650 \pm 0.02^{\mathrm{c}}$ & $0.684 \pm 0.03^{\mathrm{bc}}$ & $0.714 \pm 0.04^{\mathrm{ab}}$ \\
\hline AL/SL & $0.559 \pm 0.07^{\mathrm{a}}$ & $0.494 \pm 0.03^{c}$ & $0.522 \pm 0.04^{\mathrm{bc}}$ & $0.506 \pm 0.02^{\mathrm{bc}}$ & $0.501 \pm 0.03^{\mathrm{bc}}$ & $0.528 \pm 0.04^{\mathrm{b}}$ & $0.562 \pm 0.04^{\mathrm{a}}$ \\
\hline PL/SL & $0.598 \pm 0.05^{\mathrm{ab}}$ & $0.550 \pm 0.04^{\mathrm{bc}}$ & $0.553 \pm 0.05^{\mathrm{d}}$ & $0.577 \pm 0.02^{\mathrm{bcd}}$ & $0.569 \pm 0.02^{\mathrm{cd}}$ & $0.581 \pm 0.03^{\mathrm{bc}}$ & $0.617 \pm 0.04^{\mathrm{a}}$ \\
\hline LL/SL & $0.257 \pm 0.03^{\mathrm{c}}$ & $0.339 \pm 0.03^{\mathrm{a}}$ & $0.218 \pm 0.03^{\mathrm{d}}$ & $0.277 \pm 0.03^{\mathrm{abc}}$ & $0.270 \pm 0.03^{\mathrm{bc}}$ & $0.293 \pm 0.04^{\mathrm{ab}}$ & $0.291 \pm 0.05^{\mathrm{ab}}$ \\
\hline $\mathrm{LCT} / \mathrm{SL}$ & $0.214 \pm 0.03^{\mathrm{cd}}$ & $0.292 \pm 0.02^{\mathrm{a}}$ & $0.208 \pm 0.02^{\mathrm{d}}$ & $0.236 \pm 0.02^{\mathrm{ab}}$ & $0.226 \pm 0.02^{\mathrm{bc}}$ & $0.244 \pm 0.02^{\mathrm{a}}$ & $0.252 \pm 0.02^{\mathrm{a}}$ \\
\hline AW/SL & $0.135 \pm 0.02^{\mathrm{bc}}$ & $0.146 \pm 0.01^{\mathrm{ab}}$ & $0.128 \pm 0.02^{\mathrm{c}}$ & $0.134 \pm 0.01^{\mathrm{bc}}$ & $0.129 \pm 0.01^{\mathrm{c}}$ & $0.149 \pm 0.02^{\mathrm{a}}$ & $0.149 \pm 0.02^{\mathrm{a}}$ \\
\hline $\mathrm{PW} / \mathrm{SL}$ & $0.161 \pm 0.02^{\mathrm{b}}$ & $0.150 \pm 0.02^{\mathrm{b}}$ & $0.141 \pm 0.02^{\mathrm{c}}$ & $0.156 \pm 0.02^{\mathrm{bc}}$ & $0.160 \pm 0.02^{\mathrm{b}}$ & $0.179 \pm 0.02^{\mathrm{a}}$ & $0.185 \pm 0.02^{\mathrm{a}}$ \\
\hline LPAS/SL & $0.533 \pm 0.08^{\mathrm{c}}$ & $0.615 \pm 0.03^{\mathrm{a}}$ & $0.592 \pm 0.04^{\mathrm{ab}}$ & $0.598 \pm 0.02^{\mathrm{ab}}$ & $0.584 \pm 0.02^{\mathrm{b}}$ & $0.577 \pm 0.02^{\mathrm{b}}$ & $0.595 \pm 0.02^{\mathrm{ab}}$ \\
\hline AAAM/SL & $0.060 \pm 0.01^{\mathrm{c}}$ & $0.068 \pm 0.01^{\mathrm{c}}$ & $0.067 \pm 0.01^{\mathrm{b}}$ & $0.065 \pm 0.01^{\mathrm{bc}}$ & $0.069 \pm 0.01^{\mathrm{b}}$ & $0.071 \pm 0.01^{\mathrm{ab}}$ & $0.075 \pm 0.01^{\mathrm{a}}$ \\
\hline $\mathrm{PAPM} / \mathrm{SL}$ & $0.059 \pm 0.01^{\mathrm{d}}$ & $0.066 \pm 0.01^{\mathrm{bc}}$ & $0.065 \pm 0.01^{\mathrm{cd}}$ & $0.066 \pm 0.00^{\mathrm{bc}}$ & $0.068 \pm 0.01^{\mathrm{bc}}$ & $0.072 \pm 0.01^{\mathrm{ab}}$ & $0.077 \pm 0.01^{\mathrm{a}}$ \\
\hline $\mathrm{PVM} / \mathrm{SL}$ & $0.213 \pm 0.03^{\mathrm{abc}}$ & $0.201 \pm 0.02^{\mathrm{c}}$ & $0.213 \pm 0.02^{\mathrm{abc}}$ & $0.206 \pm 0.01^{\mathrm{c}}$ & $0.211 \pm 0.02^{\mathrm{bc}}$ & $0.228 \pm 0.02^{\mathrm{a}}$ & $0.225 \pm 0.02^{\mathrm{ab}}$ \\
\hline VPM/SL & $0.349 \pm 0.04^{\mathrm{a}}$ & $0.305 \pm 0.03^{c}$ & $0.262 \pm 0.03^{\mathrm{d}}$ & $0.276 \pm 0.02^{\mathrm{d}}$ & $0.264 \pm 0.02^{\mathrm{d}}$ & $0.339 \pm 0.03^{\mathrm{ab}}$ & $0.324 \pm 0.04^{\mathrm{bc}}$ \\
\hline
\end{tabular}

Values in the same row with difference superscripts indicate a significantly different at level $(\mathrm{p}<0.05)$

$* \mathrm{SL}=$ Standard length, $\mathrm{SH}=$ Shell height, $\mathrm{SW}=$ Shell width, UL = Umbo length, AL = Anterior length, PL = Posterior length, $\mathrm{LL}=$ Ligament length, $\mathrm{LCT}=$ Cardinal tooth length, AW = Anterior adductor muscle scar width, PW = Posterior adductor muscle scar width, LPAS = Length from anterior adductor muscle scar to posterior adductor muscle scar, AAAM = Length from anterior adductor muscle scar to anterior margin, PAPM = length from posterior adductor muscle scar to posterior margin, $\mathrm{PVM}=$ Length from ventral margin to pallial line, $\mathrm{VPM}=$ Ventral posterior margin length.

Table 3. Summary of canonical discriminant functions

\begin{tabular}{ccccc}
\hline Function & Eigen value & Variance $(\%)$ & Cumulative $(\%)$ & Canonical correlation \\
\hline 1 & 2.049 & 36.1 & 36.1 & 0.820 \\
2 & 1.787 & 31.5 & 67.5 & 0.801 \\
3 & 1.431 & 25.2 & 92.7 & 0.767 \\
\hline
\end{tabular}

\section{Genotypes Analysis}

The topology in Figure 5 was constructed using Maximum Likelihood (ML), Maximum Parsimony (MP) and Neighboring Joining (NJ). By disregarding the out-group, the topology indicates a robust dichotomous splitting two clades. However, the range separating of each clade is not significant. The C. fluminea from Terengganu (Kuala Terengganu and Marang) was separated solely at a distance of 0.0026 while the rest distributed in a large group parted at 0.01 .
In ML, three sub-groups distinguishing Temerloh (1), Tumpat and Jeli (2) and Pasir Puteh and Besut (3) with nodes support 46, 45 and 41 respectively, to the groups.

\section{DISCUSSION}

Shell characteristics are generally used to characterise mollusc species, but for closely related species, such characteristics may not be conclusive. Individuals of the same species may vary in shell characteristics due to high polymorphism and 


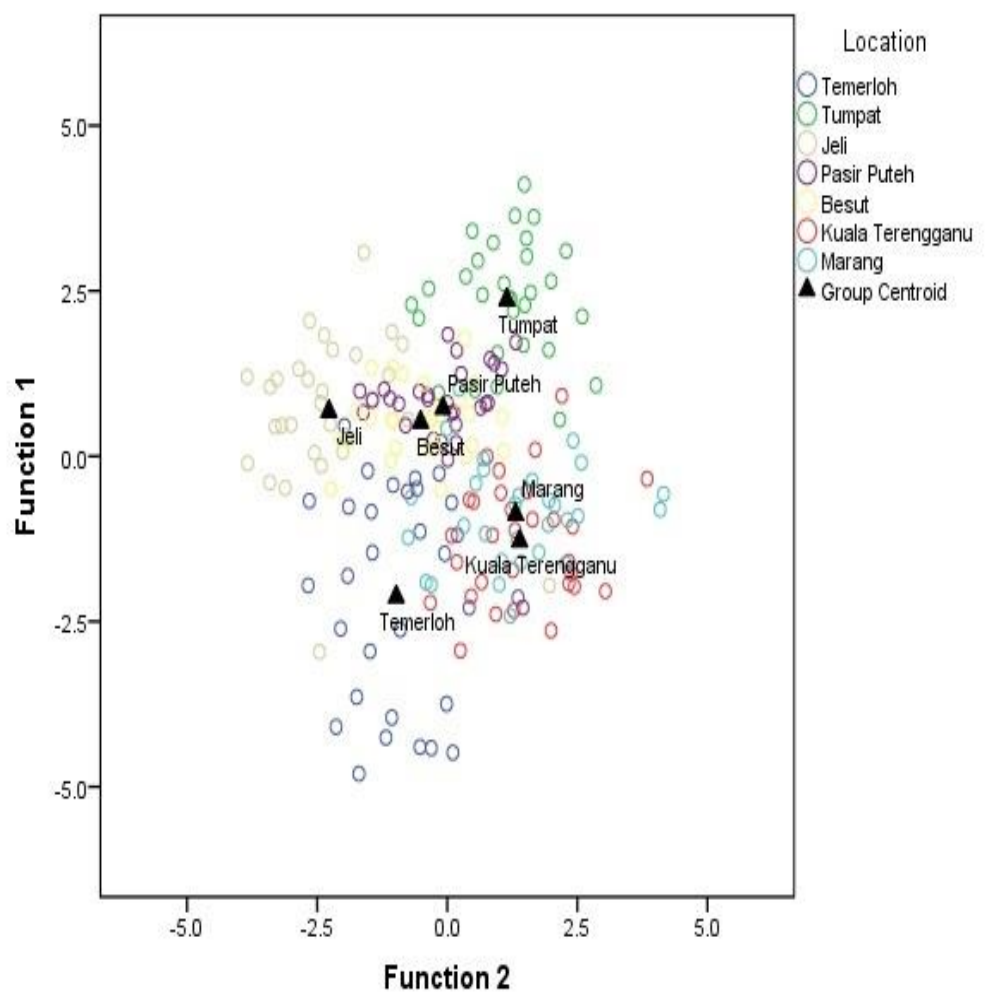

Figure 3. The canonical discriminant plots of function 1 and 2 for the morphometric characteristics (shell height, shell width and umbo length)

prone to environmental changes. Similar shell characteristics can refer to different species in Corbicula. This polymorphism characteristic distinguished many species of Corbicula and greatly contributed to their description (Renard et al., 2000). Paunovic (2007) invented a systematic method which applies to distinguish and taxonomically characterised based on shell morphotypes instead of molecular work. This approach have been reported in many studies that successfully characterise the bivalves through shell morphology (Sousa et al., 2009; Pigneur et al., 2011; Hamli et al., 2012). Recent study characterised seven populations of $C$. fluminea obtained from three states in east coast of Peninsular Malaysia. These populations are indistinctly existed in three morphometric dimensions of the shell (morphotypes). Furthermore, the $C$. fuminea is naturally exists with various inner shell colour (forms) regardless of their morphotypes. Corbicula's three general morphotypes could be described by means of the inner shell color specifically referred to as A (white), B (purple) and C (both morphs) derived from C. leana, C. fluminea and C. largillierti, respectively (Pigneur et al., 2011; Reyna et al., 2013).
Pigneur et al. (2011) proposed classification by its outer shell morphotypes; round dark-coloured $(\mathrm{R})$, saddle (S) and third form are known as round with light-coloured (Rlc). In a recent study, Corbicula was present in all morphotypes R, Rlc and $\mathrm{S}$ regardless of their inner shell colour (forms) (Figure 2). For example, R and Rlc morphotypes were found in $C$. fluminea population from the evaluated locations. Despites, their inner shell colours ranged from white to dark purple disregarding the characterisation based on the inner shell (forms).

In addition, the characteristics of polymorphism may discriminate the Corbicula by the dimension ratio, as recently applied. Heino (2014) reported that every species has a unique character that distinguishes them and formed the population structure which could be identified by morphological characters. In this study, three significant morphometric ratios of shell height (SH), shell width (SW) and umbo length (UL) are highly correlated and consistence in characterising the evaluated $C$. fluminea (Table 3). Besides, the variation in the dimension ratio of morphometric characters indicates the size and shape influence. This finding is parallel to the signs of the canonical 


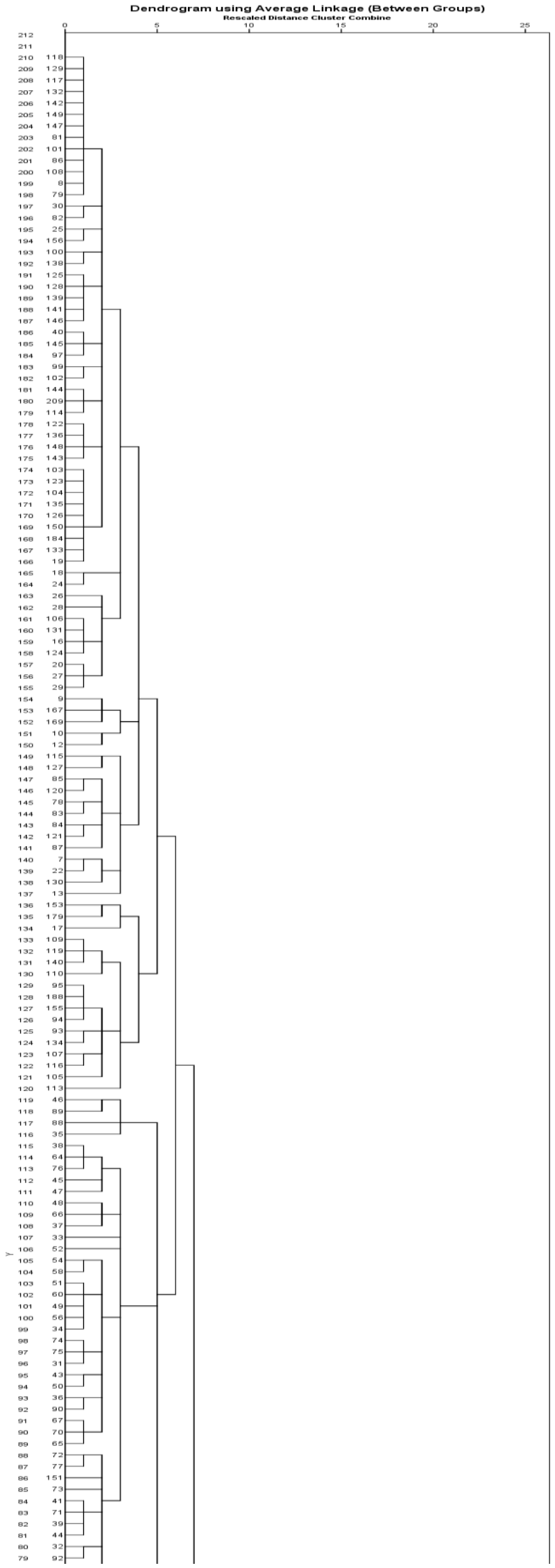

Figure 4. Dendogram obtained from three morphometric characters (shell height, shell width and umbo length) of the evaluated C. fluminea 


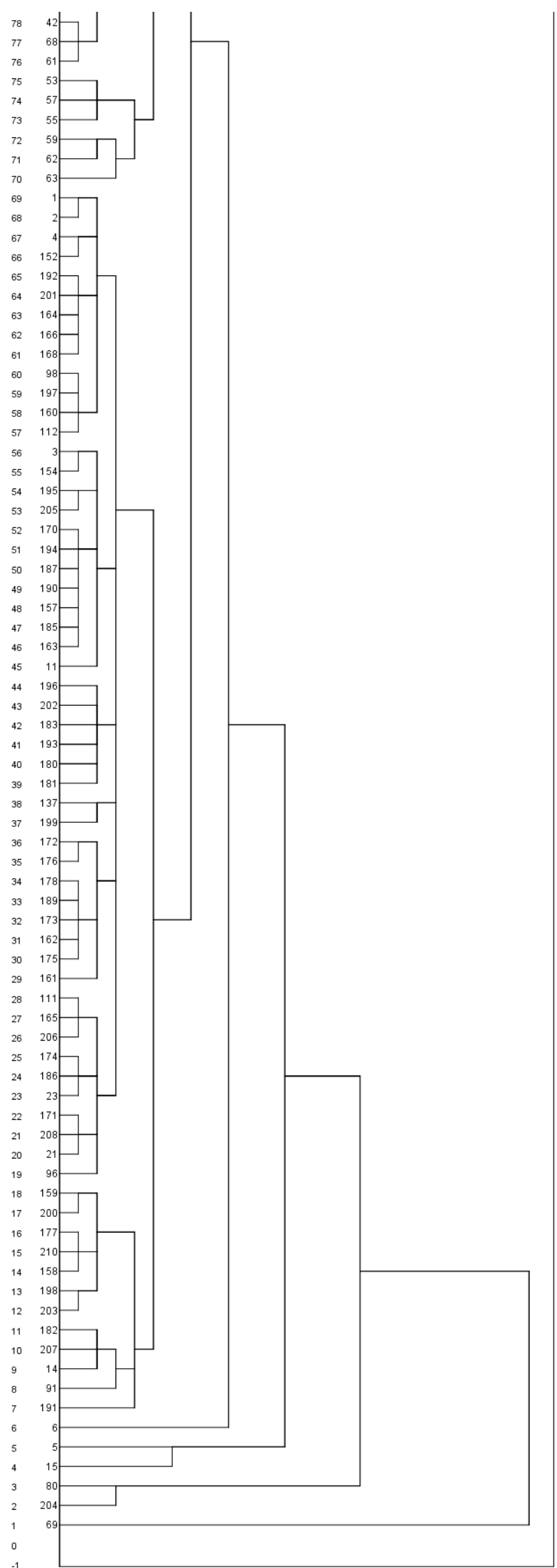

Figure 4. (continued) Dendogram obtained from three morphometric characters (shell height, shell width and umbo length) of the evaluated $C$. fluminea 


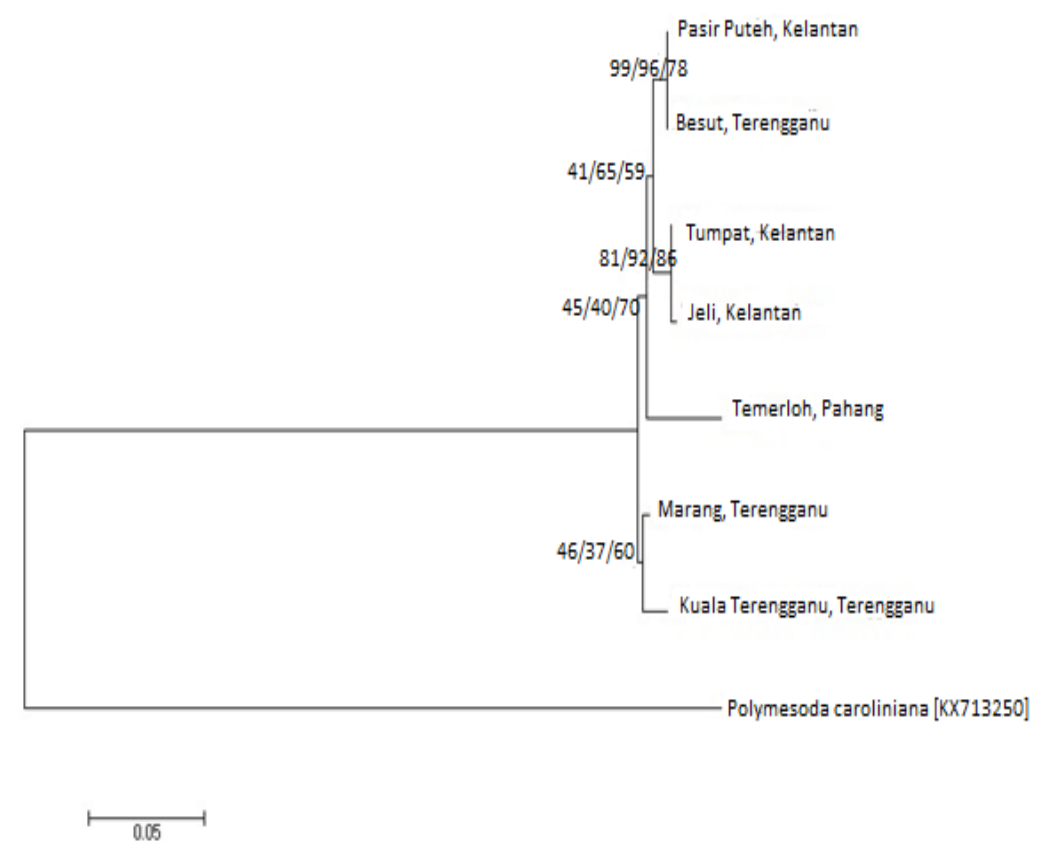

Figure 5. Phylogenetic tree constructed by the Maximum Likelihood (ML), Maximum Parsimony (MP) and Neighboring Joining (NJ) methodology using a 481-bp partial fragment of the mitochondrial gene cytochrome b (mtDNA cytb) dataset. The construction of the tree was incorporated Polymesoda caroliniana (KC713250) sequence as out-group and using the Tamura-Nei substitution model. The bootstrap values support 1000 replicates. The bootstrap values for ML, MP and NJ on the branches respectively

functions where the unequal signs of the correlation values indicate a measurement of the overall size of the $C$. fluminea shell. Nevertheless, the overlap distributions of the $C$. fluminea in the canonical discriminant topography (Figure 3) given a possibility of hybridisation or high polymorphism resulting from the environmental factors which require additional analysis to elucidate the occurrence. Therefore, in the recent study, the cluster analysis confirmed that the morphometric characters of $C$. fluminea evaluated were overlapped and these overlapping morphometric characters hardly discriminate one location from another (Figure 4).

On the other hand, a recent study compared the local specimens with the holotypes of Corbicula deposited in Mollusk Museum, Mahidol University, Thailand. Various paratypes of the Corbicula were recorded in the museum where most of the specimens came from Thailand waters (Table 1). For instance, $C$. fluminea and $C$. lamarkiana were found inhabited similar habitat in Chao Praya River and the morphotypes were found identical. There is no further information on how they were named but in this study, it is appropriate to synonymise the $C$. lamarkiana as $C$. fluminea based on previous literatures (Glaubrecht et al.,
2006; Hedtke et al., 2008; Bódis et al., 2011). These taxa misnamed have been discussed extensively in many previous research where currently many taxa were synonymised to recognised species such as $C$. fluminea and $C$. fluminalis (Morton, 1987; Renard et al., 2000; Morden, 2015). Meanwhile, Corbicula specimens could demonstrate different morphotypes although shared a similar taxa name, colonised different habitat, and used a similar water source. As an example, two morphotypes ( $\mathrm{R}$ and Rlc) distinguished the $C$. fluminea inhabited River Ping which is flowing from Chiang Mai to Kamphaeng Phet, Thailand. In this case, the existed $C$. fluminea in this river may have similar lineage although different habitat conditions had influenced their morphotypes. Furthermore, the dispersion behaviour of the $C$. fluminea such as drifting during planktonic juveniles had to assist them to occupy the river bed and its tributaries across geography.

Observation in the recent study could relate this theory which was found in $C$. fluminea inhabited Kuala Terengganu and Marang where the corresponding rivers were sourced from the Lake Kenyir. However, the $C$. fluminea was found to be diverged in morphotypes especially $\mathrm{S}$ morphotypes that dominated Kuala Terengganu populations and 
an Rlc in the Marang population (Figure 2). A similar morphotype of $C$. fluminea was found in two different water sources such as Pasir Puteh and Besut. In this case, both locations were in different states but similar topography provides identical habitat conditions. Hence, this circumstance describes the environmental factors that had led to their variation in morphotypes, not adequate to assert their species variation.

The $C$. fluminea could live in a lentic and lotic habitat with different substrates components across the geographical range (Sousa et al., 2009; Rosa, 2013). Hence, the substratum components have significantly influenced the shell colour and shape. Typically, yellow shell Corbicula was found in high-flowing sandy rivers while brown and purple shell inhabit substrate consists of the mixture of sands and mud. For instance, $C$. fluminea (round with yellow and black shell colour) was found to populate sandy loam and loamy sand substrates in Pattani and Saiburi rivers respectively (Zaween $e t$ al., 2017). C. fluminea with $\mathrm{R}$ morphotypes inhabited lentic habitat could obviously be seen at Tumpat and Jeli, according to recent findings. These two areas comprise of different conditions; In Tumapt the paddy field is surrounded by the water canal, while Jeli samples were obtained from a dam. Meanwhile, $C$. fluminea in Kuala Terengganu was dominated by yellow coloured $\mathrm{S}$ morphotypes as they populated lotic habitat near the estuary. A similar observation could be seen in the paratype of $C$. ostriorum that was found in Ta Pi River, Surat Thani, Thailand. Thus, the morphotypes exhibited in this area may result in response to salinity influences. Nevertheless, it is immature to conclude the shell plasticity is due to the salinity influences since there are holotypes with $\mathrm{S}$ morphotypes can also be found in freshwaters (Table 1). Therefore, Corbicula is could be appropriately characterised through morphotypes in consideration with the habitat, as the plasticity of the shell may be influenced by the environmental factors.

The morphotypes variation has resulted from several factors like evolution in genetics constituents and environmental influences or their interactions. Recent findings mainly found three morphotypes (R, Rlc and S) which may suggest three species or one species with different morphotypes. But then again, it is inappropriate to conclude the taxa without the genetic assistance since the polymorphism of shells are derived from the diverse genetic constituents.
Two lineages of Corbicula were found sympatrically inhabited River Rhine which producing cryptic hybrids as well (Pfenninger et al., 2012). In more recent work, the taxa cannot be differentiated through molecular approaches of two populations Corbicula found in the Minho and Lima estuaries although they show significant differences in their morphological characteristics (Sousa et al., 2009). These findings demonstrated different morphotypes of Corbicula that possibly shared similar lineage but experienced different microenvironmental factors. Also, this situation could be contributed by the incomplete reproductive isolation incidence due to androgenesis characteristic in Corbicula (Bódis et al., 2011; Pigneur et al., 2012). The androgenesis in Corbicula requires further study to comprehend their reproductive modes influencing the phenotypes and genotypes. The genetic evidence is therefore needed as a complement to the phenotype characterisation to avoid misnaming taxa.

The present study verifies the existence of Corbicula as $C$. fluminea based on the analysis of mtDNA cytb genes. This gene marker is reliable to be used since it has proved that genetics analysis was not following the phenotypic analysis of $C$. fluminea and C. leana (Yamada et al., 2009). Moreover, researchers had employed this mtDNA marker in characterising the Corbicula samples in Portugal (Gomes et al., 2016) and proved the genetics polymorphism of ten $C$. fluminea populations in Hongze Lake, China (Zhu et al., 2018). Particularly in a recent study, the similar topology of phylogenetic trees demonstrated that C. fluminea coincided with the morphotypes and may also elucidate their lineages (Figure 5). For example, a small divergence between $C$. fluminea from Jeli and Tumpat may suggest the same origin, Kelantan River. A similar observation could be seen between $C$. fluminea from Besut and Pasir Puteh, Kuala Terengganu and Marang as well. Temerloh population located in the phylogenetic tree that explains the geographical separation, although is not significant. This finding strongly recommended the use of mtDNA cytb gene in genetics analysis since it could be useful in detecting the intraspecific low-level sequence divergences.

On the other hand, the Jeli population seems to be isolated not just in the variation of the morphotypes but also allopatric effects in genetics. Furthermore, the existence of the Jeli population was believed due to the construction of the dam. 
Sand from Kelantan River which containing Corbicula was dumped into the dam and allow the clam to populate the dam bed until now. This occurrence has eventually split their genetics which could be seen in recent phylogenetic trees. In Terengganu, the Kuala Terengganu population is the only inhabitants that influenced by brackish water. Meanwhile, $C$. fluminea populations in Besut inhabited freshwaters similar to the Pasir Puteh population. This finding may be explained by the local trading activity between these two neighbouring districts where the harvester kept the live clams and introduced them into the river. Although the genetic evidence shows the similarity (Figure 5), their morphotypes were found to differ from each other which revealed the local adaptation. This occurrence is in agreement with Shapiro et al. (2016) which explained that the incompatibility of genes combination leads to isolation or adapting to niches necessities. Hence, slow divergence in genetics such as in recent study had portrayed polymorphism in morphotypes.

\section{CONCLUSION}

Polymorphisms of phenotypes between species have been characterised although not sufficient to tell their genetic makeup. The intermingled patterns detected between population phenotypes and genotypes revealed the low genetic diversity of $C$. fluminea. Further study is required to extend the understanding of genetics polymorphism which could be used in resource management for conservation or hatchery productions.

\section{ACKNOWLEDGMENTS}

This paper is part of the doctorate thesis which was fully supported by the Ministry of Education Malaysia under the Transdisciplinary Research Grant Scheme (TRGS) with the grant number of R/TRGS/A0.700/00387A/007/2016/000391.

\section{REFERENCES}

Araujo, R., Moreno, D. \& Ramos, M.A. (1993). The Asiatic clam Corbicula fluminea in Europe. American Malacological Bulletin, 10: 39-49.

Bódis, E., Nosek, J., Oertel, N., Tóth, B. \& Fehér, Z. (2011). A comparative study of two Corbicula morphs (Bivalvia, Corbiculidae) inhabiting River Danube. International Review of Hydrobiology, 96: 257-273.
Cheng, K.M. (2015). The Asian clam Corbicula fluminea: Seasonal filtration rates of representative populations in two tributaries of the Delaware River. (Master thesis), Drexel University.

Desjardins, P. \& Conklin, D. (2010). NanoDrop microvolume quantitation of nucleic acids. Journal Visualised Experiments, 45: e2565.

Glaubrecht, M., Fehér, Z. \& Von Rintelen, T. (2006). Brooding in Corbicula madagascariensis (Bivalvia, Corbiculidae) and the repeated evolution of viviparity in Corbiculids. Zoologica Scripta, 35: 641-654.

Gomes, C., Sousa, R., Mendes, T., Borges, R., Vilares, P., Vasconcelos, V. \& Antunes, A. (2016). Low genetic diversity and high invasion success of Corbicula fluminea (Bivalvia, Corbiculidae) (Müller, 1774) in Portugal. PLoS ONE, 11: 1-16.

Hamli, H., Idris, M.H., Abu Hena, M.K. \& Wong, S.K. (2012). Taxonomic study of edible bivalve from selected division of Sarawak, Malaysia. International Journal of Zoological Research, 8: 52 58.

Hamli, H., Rahim, A.A., Idris, M.H., Kamal, A.H.M. \& King, W.S. (2015). Morphometric variation among three local mangrove clam species of Corbiculidae. Songklanakarin. Journal of Science and Technology, 37: 15-20.

Hedtke, S.M., Stanger-Hall, K., Baker, R.J. \& Hillis, D. M. (2008). All-male asexuality: Arigin and maintenance of androgenesis in the Asian clam Corbicula. Evolution, 62: 1119-1136.

Heino, M. (2014). Quantitative traits. In Cadrin, S.X., Kerr, L.A. \& Mariani, S. (Eds.). Stock identification methods. USA. Elsevier. Pp 59-76.

Hillis, D.M. \& Patton, J.C. (1982). Morphological and electrophoretic evidence for two species of Corbicula (Bivalvia: Corbiculidae) in North America. The American Midland Naturalist, 108: 74-80.

Mackie, G.L. \& Claudi, R. (2009) (Eds.). Monitoring and control of macrofouling mollusks in fresh water system. Second Edition. USA: CRC Press.

Magare, V.N., Kulkarnii, C.P., Maurya, C.B., Patil, R.C. \& Upadhye, M.V. (2015). Phylogenetic analysis of freshwater mussel Corbicula regularis by $18 \mathrm{~S}$ rRNA gene sequencing. Journal of Experimental Biology and Agricultural Sciences, 3(2): 213-219. 
Morden, A. (2015). The northern range extension of the invasive bivalve Corbicula fluminea, (December). (Master thesis), McGill University, Montreal.

Morton, B.S. (1987). Polymorphism in Corbicula fluminea (Bivalvia: Corbiculidae) from Hong Kong. Malacology Revision, 20: 105-127.

Park, J.K. \& Kim, W. (2003). Two Corbicula (Corbiculidae: Bivalvia) mitochondrial lineages are widely distributed in Asian freshwater environment. Molecular Phylogenetics and Evolution, 29: 529539.

Paunovic, M. (2007). Distribution of Asian clams Corbicula fluminea and C. fluminalis in Serbia. Aquatic Invasions, 2: 99-106.

Peñarrubia, L., Araguas, R.M., Vidal, O., Pla, C., Viñas, J. \& Sanz, N. (2017). Genetic characterization of the Asian clam species complex (Corbicula) invasion in the Iberian Peninsula. Hydrobiologia, 784: 349365 .

Pfenninger, M., Reinhardt, F. \& Streit, B. (2002). Evidence for cryptic hybridization between different evolutionary lineages of the invasive clam genus Corbicula (Veneroida, Bivalvia). Journal Evolution Biology, 15: 818-829.

Pigneur, L.M., Risterucci, A.M., Dauchot, N., Li, X. \& Van Doninck, K. (2011). Development of novel microsatellite markers to identify the different invasive lineages in the Corbicula complex and to assess androgenesis. Molecular Ecology Resources, 11: 573-577.

Pigneur, L.M., Hedtke, S.M., Etoundi, E. \& Van Doninck, K. (2012). Androgenesis: a review through the study of the selfish shellfish Corbicula spp. Heredity, 108: 581-91.

Prashad, B. (1940). On a new species of the genus Corbicula Meg. von Mühlfeldt from Perak. Bulletin of the Raffles Museum, 16: 119-120.

Renard, E., Bachmann, V., Cariou, M.L. \& Moreteau, J.C. (2000). Morphological and molecular differentiation of invasive freshwater species of the genus Corbicula (Bivalvia, Corbiculidea) suggest the presence of three taxa in French rivers. Molecular Ecology, 9: 2009-2016.

Reyna, P., Scientific, N., Scientific, N. \& Scientific, N. (2013). Taxonomy, distribution and population structure of invasive Corbiculidae (Mollusca, Bivalvia) in the Suquía River basin. Serie Zoologica, 103(2): 77-84.

Rosa, I.C. (2013). The Asian clam: Dispersal, impacts and potential benefits. ( $\mathrm{PhD}$ Thesis), Universidade Do Porto.

Sambrook, J. \& Russell, D.W. (2001). Molecular cloning: a laboratory manual. Third Edition. New York: Cold Spring Harbor Laboratory Press. Pp 463-464.

Schmidlin, S. (2011). Introduction, spread and establishment of the invasive clam Corbicula spp. in Switzerland. (PhD Thesis), Universität Basel.

Serdar, S. (2018). Growth of the Asian clam Corbicula fluminea (Muller, 1774) cultured in Cine Creek, Aydin, Turkey. Journal of Shellfish Research, 37(3): 491-496.

Shapiro, B.J., Leducq, J. \& Mallet, J. (2016). What is speciation? PloS Genetics, 12: 1-14.

Sousa, R., Freire, R., Méndez, J., Rufino, M., Gaspar, M., Antunes, C. \& Guilhermino, L. (2009). The Asiatic clam Corbicula fluminea (Müller, 1774) in the Minho and Lima estuaries: genetic vs. morphometry. Annales de Limnologie, Bivalvia, 499.

Yamada, M.I., Ishibashi, R., Kawamura, K. \& Komaru, A. (2010). Interrelationships of the freshwater clams Corbicula leana Prime, 1864 and C. fluminea (Mäuller, 1774) distributed in Japan inferred from shell type and mitochondrial DNA Cyt $b$ region. Nippon Suisan Gakkaishi, 76(5): 926-932.

Zaween, N.S.M., Rak, A.E.H., Aisyah, S., Omar, S. \& Afip, L.A. (2017). Preliminary assessment of Corbicula fluminea in Saiburi River. Borneo Journal of Resource Science and Technology, 7: 76-83.

Zeswita, A.L., Zakaria, I.J. \& Salmah, S. (2016). Reproductive characters of fresh water shellfish (Corbicula sumatrana Clessin) in Singkarak Lake West Sumatra Indonesia. Journal of Entomology and Zoology Studies, 4: 374-377.

Zhu, C., Li, J., Xie, S., Ding, H., Pan, Z., Wang, H. \& Chang, G. (2018). Genetic diversity analysis of Asian clam Corbicula fluminea in the Hongze Lake based on mitochondrial cytochrome b gene. Mitochondrial DNA Part A, 29: 1-8. 